\title{
Article \\ Foliar Application of Auxin or Cytokinin Can Confer Salinity Stress Tolerance in Vicia faba L.
}

\author{
Arafat Abdel Hamed Abdel Latef ${ }^{1, *(\mathbb{D})}$, Ayasha Akter ${ }^{2,+(\mathbb{D})}$ and Md. Tahjib-Ul-Arif ${ }^{3,+}$ (D) \\ 1 Department of Biology, Turabah University College, Turabah Branch, Taif University, P.O. Box 11099, \\ Taif 21944, Saudi Arabia \\ 2 Department of Horticulture, Bangladesh Agricultural University, Mymensingh 2202, Bangladesh; \\ aakterhort@bau.edu.bd \\ 3 Department of Biochemistry and Molecular Biology, Bangladesh Agricultural University, \\ Mymensingh 2202, Bangladesh; tahjib@bau.edu.bd \\ * Correspondence: a.moawd@tu.edu.sa or moawad76@gmail.com \\ + Authors contributed equally.
}

Citation: Abdel Latef, A.A.H.; Akter,

A.; Tahjib-Ul-Arif, M.. Foliar

Application of Auxin or Cytokinin Can Confer Salinity Stress Tolerance in Vicia faba L.. Agronomy 2021, 11, 790. https://doi.org/10.3390/ agronomy 11040790

Academic Editor: Charles T. Hunter

Received: 3 March 2021

Accepted: 15 April 2021

Published: 16 April 2021

Publisher's Note: MDPI stays neutral with regard to jurisdictional claims in published maps and institutional affiliations.

Copyright: (c) 2021 by the authors. Licensee MDPI, Basel, Switzerland. This article is an open access article distributed under the terms and conditions of the Creative Commons Attribution (CC BY) license (https:// creativecommons.org/licenses/by/ $4.0 /)$.

\begin{abstract}
Soil salinity severely declines the availability of water and essential minerals to the plants, which hinders growth. The present study evaluates the potential roles of indole-3-acetic acid (IAA) and 6-benzyladenine (BA) for mitigating the adverse effects of soil-salinity in faba bean (Vicia faba L.). Plants were exposed to $150 \mathrm{mM} \mathrm{NaCl}$ stress and were sprayed with IAA (1.15 mM) or BA (0.9 mM). Our results revealed that foliar application of IAA or BA improved the growth traits of salinized faba bean due to the increased uptake of $\mathrm{K}^{+}, \mathrm{Ca}^{2+}$, and $\mathrm{Mg}^{2+}$ ions, accumulation of free amino acids, soluble sugars, and soluble proteins, and activity of superoxide dismutase, catalase, peroxidase, and ascorbate peroxidase. The principal component analysis (PCA) and heatmap clustering indicated that salinity-exposed plants exhibited lower growth and biomass production, which correlated with higher accumulation of $\mathrm{Na}^{+}$and malondialdehyde. Moreover, electrophoretic patterns of protein showed new bands in IAA- or BA-treated salt-stressed plants, indicating that IAA or BA treatment can reprogram the metabolic processes to confer salinity tolerance. We also found that IAA has a greater capacity to ameliorate the salt stress than BA, although there is no significant difference in yield between these treatments. Finally, these findings can be helpful for a better understanding of IAA- and BA-mediated salt tolerance mechanisms and increasing production of faba bean in saline soils.
\end{abstract}

Keywords: antioxidants; faba bean; indole-3-acetic acid; phytohormone; protein electrophoresis; salt stress; 6-benzyladenine

\section{Introduction}

Plants are often exposed to a variety of environmental stresses such as salinity, drought, and temperature that have undesirable consequences on their growth and biomass production [1]. Soil salinity is one of the devastating abiotic stresses limiting crop growth and productivity worldwide [1-3]. Salinity mainly hinders many physio-chemical processes in plants including seed germination [4], seedling establishment [5], enzymatic activities [6], and DNA, RNA, and protein synthesis [7]. According to some scientists, nearly one-fifth of irrigated lands are salt-affected, implying that one-third of the world's food-producing area is affected [8]. Following this, most of the fertile lands would be affected by salt intrusion by the mid-twentieth century [9]. This is a serious issue because saline areas are expanding at a rate of $10 \%$ annually, which would be exacerbated by increased global warming and climatic changes [10].

Salinity in nature is a dynamic environmental constraint caused primarily by the presence of excessive salts in rooting media. Initially, salinity causes osmotic stress in plants and directly affects the metabolic processes [11]. Later, salinity causes ionic toxicity 
because of the over-accumulation of $\mathrm{Na}^{+}$and $\mathrm{Cl}^{-}$ions in cells [11]. Furthermore, it causes nutrient imbalance by hindering the absorption of required mineral nutrients [11]. Various morpho-physiological and biochemical alterations emerge due to the ionic misbalance in plants, especially at early growth stages [12]. Salinity-induced water insufficiency and nutrient such as $\mathrm{Ca}^{2+}, \mathrm{K}^{+}, \mathrm{Fe}^{2+}$, and $\mathrm{Zn}^{2+}$ deficiency within plants leads to photosynthesis disruption and oxidative stress [13]. Overall, salinity causes the reduction of leaf area, stomatal conductance, and chlorophyll levels in the plants [14] and promotes the generation of reactive oxygen species (ROS) [15].

It is an important challenge for researchers to address the declining food production and ensure food supply for the ever-increasing population by enhancing crop plant tolerance to salinity [16]. Various mitigation and adaptation methods of salt tolerance in plants have already been studied to overcome the worst conditions of high soil salinity [17]. Some researchers have employed plant growth regulators (PGRs) to mitigate the adverse effects of salinity on plants $[11,18]$.

Phytohormones, often known as PGRs, are small bioactive compounds synthesized by plants that can act locally or transport to the distant sites of the plant body to accelerate growth and development in both non-stress and stressful conditions [19,20]. Growth and developmental processes are also regulated by the applications of several PGRs including auxin [21] and cytokinins (CKs) [22]. These PGRs can alleviate the negative effects of salt stress by increasing seed germination, growth, development, and yield [23]. One of the most common auxins produced by plants is indole-3-acetic acid (IAA), which is the first identified plant hormone [24,25]. Reports show that IAA also governs plant growth response in different crop plants under salt stress including in Triticum Durum [26], Lycopersicon esculentum L. [27], and Zea mays L. [28]. Seed priming with IAA effectively diminished the adverse effects of salt stress on seed germination and plant growth of Triticum aestivum [29] and Zea mays [28]. CKs also promote plant growth aspects and the developmental process and plant adaptation to stress [23,30,31]. 6-Benzylaminpurine (BA) is a synthetic analog of cytokinin that acts the same as other naturally occurring cytokinins [32]. Naturally, CKs are produced in the plant root tips and developing seeds [33]. Applications of CKs including BA have been described to mitigate various abiotic stresses (e.g., salinity in Solanum melongena Mill. [34], drought in Zea mays [35], and waterlogging in Zea mays [36]).

Faba bean, which belongs to the family Fabaceae, is the third most important legume crop and is cultivated in more than 60 countries as a cool-season legume [37]. In semi-arid regions, saline soils severely constrain the productivity of faba bean [38] and result in a maximum 50\% yield loss [39]. Remembering the adverse effects of salinity on faba bean plants, this research work was designed to realize the effects of exogenous IAA or BA on the growth and growth-related parameters of faba bean under saline conditions for mitigating salt stress and promoting salt tolerance mechanisms. Furthermore, for the first time, our research compared the efficacy of IAA and BA in faba bean salinity stress mitigation.

\section{Materials and Methods}

\subsection{Plant Material, Treatment, and Experimental Design}

This experiment was carried out under greenhouse conditions with relative humidity of $65-75 \%$ and average night and day temperature ranging from 27 to $35^{\circ} \mathrm{C}$. At first, faba bean, cultivar Assiut 80 Roomy, seeds were surface-sterilized for 5 min using mercuric chloride $(0.1 \%)$ and washed thoroughly using distilled water several times. After that, 10 seeds were sown in each pot filled with $5 \mathrm{~kg}$ of air-dried soil (sand:clay, 3:1 $v / v$ ). To add the nutrient and treatment solutions, a $15-\mathrm{cm}$ long perforated plastic pipe was inserted into the soil of each pot. Proper moisture condition was maintained by daily irrigation with tap water and a stable osmotic potential was maintained for uniform seed germination. After germination, plants were thinned out and each pot contained five faba bean plants. On the 14th day after sowing, germinated faba bean seedlings were exposed to salinity stress. 
The experimental design was based on a combination of two factors: stress (salinity, 0 and $150 \mathrm{mM} \mathrm{NaCl}$ ) and exogenous treatment (IAA or BA). Plants were exposed to two salinity levels, $0 \mathrm{mM} \mathrm{NaCl}$ and $150 \mathrm{mM} \mathrm{NaCl}$ and spayed with water or $1.15 \mathrm{mM}$ IAA or $0.9 \mathrm{mM}$ BA. A constant volume (50 mL per pot) of IAA or BA was sprayed using a hand pump sprayer. Tween-20 (0.1\%) was added to ensure maximum delivery of IAA or BA to the leaves. To avoid light-induced degradation of those phytohormones, we usually sprayed plants during the evening. IAA or BA solutions were applied two times 10 and 20 days after salinization. We kept the IAA or BA application method simple so that it could be readily useable for farmers. Several previous studies have shown that exogenous IAA or BA mediates plant physiological responses [26-28,34-36], indicating that exogenous IAA or BA may penetrate the plant system. Thus, there were six treatment conditions as follows: (i) control (C), $0 \mathrm{mM} \mathrm{NaCl}$ water spray; (ii) $150 \mathrm{mM} \mathrm{NaCl}+$ water spray (S); (iii) $0 \mathrm{mM} \mathrm{NaCl}+1.15 \mathrm{mM}$ IAA (IAA); (iv) $150 \mathrm{mM} \mathrm{NaCl}+1.15 \mathrm{mM}$ IAA (S + IAA); (v) $0 \mathrm{mM} \mathrm{NaCl}+0.9 \mathrm{mM} \mathrm{BA}$ (BA); and (vi) $150 \mathrm{mM} \mathrm{NaCl}+0.9 \mathrm{mM} \mathrm{BA}(\mathrm{S}+\mathrm{BA})$. This experiment was designed as a completely randomized model with three replications for each treatment and each replication contained five faba bean plants. The plants were grown under these treatment conditions for 120 days.

\subsection{Measurement of Plant Growth Parameters}

After 105 days of salinization, measurement of the root fresh weight (RFW), shoot fresh weight (SFW), leaf fresh weight (LFW), root dry weight (RDW), shoot dry weight (SDW), and leaf dry weight (LDW) were recorded from 15 plants. These dry weights were measured after drying in an aerated oven at $80{ }^{\circ} \mathrm{C}$ for $96 \mathrm{~h}$ to reach a constant weight. Samples were also ground and stored for different chemical analyses. Leaf area (LA) was measured using the disk model described by [40]. At the harvest stage, 120 days after sowing (DAS), the number of nodules, fresh yield, and dry yield were recorded.

\subsection{Extraction and Analysis of Proline, Soluble Sugars, Soluble Proteins, and Free Amino Acid Contents}

All these parameters were determined using the fresh leaves of plants. Proline extraction and determination were done according to the description of [41]. Soluble sugar (SS) content was determined according to the published method [42] based on anthrone-sulfuric acid. Soluble protein (SP) content was determined following the method of [43] using bovine serum albumin as the standard. The content of total free amino acids (FAA) was estimated by following the protocol of [44].

\subsection{Estimation of Different Mineral Ion Contents}

Different plant parts of faba bean (i.e., root, stem, leaf, and seed) were harvested and rinsed with deionized water. Fresh samples were dried in the oven at $70{ }^{\circ} \mathrm{C}$ for $96 \mathrm{~h}$. Dried plant parts were fully ground and treated with $\mathrm{HNO}_{3}: \mathrm{HClO}_{4}(2: 1 \mathrm{v} / \mathrm{v})$ for $2 \mathrm{~h}$ at $220{ }^{\circ} \mathrm{C}$ following the protocol of [45]. The contents of $\mathrm{Na}^{+}$and $\mathrm{K}^{+}$were analyzed by an atomic absorption flame spectrophotometer (Model AA-6400 F, Shimadzu Corporation, Kyoto, Japan). The $\mathrm{Ca}^{2+}$ and $\mathrm{Mg}^{2+}$ contents were determined using the versene (disodium dihydrogen ethylene-diamine-tetraacetic acid) method of titration [46].

\subsection{Measurement of Lipid Peroxidation}

Heath and Packer [47] described the procedure for measuring the level of lipid peroxidation in the term of malondialdehyde (MDA). Fresh leaves ( $0.2 \mathrm{~g})$ of plants were homogenized with $5 \mathrm{~mL}$ of $5 \%$ trichloroacetic acid (TCA) solution and centrifuged at $15000 \times g$ for $10 \mathrm{~min}$ at $4{ }^{\circ} \mathrm{C}$. Along with $4 \mathrm{~mL}$ of $20 \%$ TCA containing $0.5 \%$ thiobarbituric acid solution, $2 \mathrm{~mL}$ aliquot of the supernatant was added. Then the mixtures were kept incubated for $30 \mathrm{~min}$ at $95^{\circ} \mathrm{C}$ and immediately transferred in an ice bath and centrifuged at $10,000 \times g$ for $10 \mathrm{~min}$. Then, the supernatant was quickly placed in an ice bath and repeated in the centrifuge for $10 \mathrm{~min}$ at $11,000 \times \mathrm{g}$. The supernatant absorption and the non-specific 
absorption value were quantified at $532 \mathrm{~nm}$ and $600 \mathrm{~nm}$, respectively. The MDA content was estimated by employing the absorption coefficient of $155 \mathrm{nM}^{-1} \mathrm{~cm}^{-1}$.

\subsection{Extraction and Determination of Antioxidant Enzymatic Activity}

Mukherjee and Choudhuri [48] described the procedure for different enzyme extraction. First, $0.2 \mathrm{~g}$ of the fresh leaf sample of day-old plants was taken with liquid nitrogen and finely ground using a chilled mortar and pestle and added $5 \mathrm{~mL}$ of $100 \mathrm{mM}$ potassium-phosphate of (K-P) buffer (100 mM, pH 7.0) with disodium EDTA (0.1 mM) and polyvinylpyrrolidone $(0.1 \mathrm{~g})$. The homogenized sample was filtered with cheesecloth and centrifuged at $15,000 \times \mathrm{g}$ for $10 \mathrm{~min}$ at $4{ }^{\circ} \mathrm{C}$ and the supernatant was used for the analysis of the following antioxidant assay such as superoxide dismutase (SOD; EC 1.15.1.1), catalase (CAT; EC 1.11.1.6), peroxidase (POD; EC 1.11.1.7), and ascorbate peroxidase (APX; EC 1.11.1.11). Scebba et al. [49] described the protocol for measuring the SOD activity. Determination of CAT activity was performed based on Aebi [50]. The method of Maehly and Chance [51] was used to determine the POD activity. The decreased absorbance at $290 \mathrm{~nm}$ as ascorbic acid was oxidized determined the APX activity [52]. All spectrometric readings were taken through a Spectronic Genysis ${ }^{1 \mathrm{M}} 2 \mathrm{PC}$ spectrophotometer (Spectronic Instruments, Waltham, MA, USA).

\subsection{Electrophoretic Detection of Protein by Sodium Dodecyl Sulfate-Polyacrylamide Gel Electrophoresis}

Electrophoretic patterns of protein were identified by sodium dodecyl sulfate-polyacrylamide gel electrophoresis (SDS-PAGE) following the procedure of [53] and [54].

\subsection{Statistical Analysis}

One-way analysis of variance (ANOVA) was performed followed by performing Tukey's test $(p<0.05)$ using the 'multcompView' package of the statistical programming language R 3.6.1. The 'pheatmap' package was used for constructing heatmap and hierarchical clustering considering Euclidean distances and 'ggplot2', 'factoextra', and 'FactoMineR' packages were used for principal component analysis (PCA) in R 3.6.1.

\section{Results}

\subsection{Foliar Applications of IAA or BA Improved Plant Growth and Yield Components}

The salt-stressed faba bean plants showed a considerable decrease in all growth parameters such as RFW, RDW, SFW, SDW, LFW, LDW, LA, and number of nodules as well as fresh and dry yields than the non-stressed plants (Table 1). However, IAAand BA-treated plants, 'S + IAA' and 'S + BA', exhibited a considerable increase in these growth traits and yields of faba bean under salinity stress conditions. Particularly, in saltstressed faba bean plants, foliar application of IAA (S + IAA) and BA (S + BA) increased RFW (by 59.2\% and 49.5\%), RDW (by 38.9\% and 30.5\%), SFW (by 28.8 and $26.6 \%$ ), SDW (by $32.9 \%$ and $28.9 \%$ ), LFW (by 9.6 and 7.0\%), LDW (by $25.5 \%$ and $22.2 \%$ ), fresh yield (36.8 and $33.0 \%$ ), dry yield (59.8\% and $63.8 \%$ ), number of nodules $(160.7 \%$ and $151.9 \%$ ), and LA (30.4 and $27.6 \%)$, respectively. The positive effects on all growth traits and yield of IAA or BA treatments on 'S + IAA' and 'S + BA' faba bean plants were almost comparable (Table 1). Furthermore, 'IAA' and 'BA' plants showed a significant increment of all studied growth and yield parameters than the control plants (Table 1). 
Table 1. Effects of foliar applications indole-3-acetic acid (IAA) or 6-benzyladenine (BA) on growth and yield components of faba bean grown under salt stress.

\begin{tabular}{|c|c|c|c|c|c|c|c|c|c|c|}
\hline Treatment & RFW (g) & RDW (mg) & SFW (g) & SDW (mg) & LFW (g) & LDW (mg) & Fresh Yield (g) & Dry Yield (g) & No. of Nodules & LA $\left(\mathrm{cm}^{2}\right)$ \\
\hline $\mathrm{C}$ & $2.11 \pm 0.02 \mathrm{~d}$ & $183 \pm 1.76 \mathrm{e}$ & $3.34 \pm 0.02 \mathrm{~d}$ & $531 \pm 1.20 \mathrm{~d}$ & $3.42 \pm 0.03 \mathrm{~d}$ & $372 \pm 3.48 \mathrm{~d}$ & $2.78 \pm 0.04 d$ & $1.70 \pm 0.03 b c$ & $2.30 \pm 0.02 d$ & $20.90 \pm 0.17 d$ \\
\hline$S$ & $\begin{array}{c}1.03 \pm 0.01 a \\
(-51.2)\end{array}$ & $\begin{array}{c}95 \pm 3.18 \mathrm{a} \\
(-48.1)\end{array}$ & $\begin{array}{c}2.29 \pm 0.02 \mathrm{a} \\
(-31.4)\end{array}$ & $\begin{array}{c}291 \pm 2.40 \mathrm{a} \\
(-45.1)\end{array}$ & $\begin{array}{c}2.60 \pm 0.03 a \\
(-23.9)\end{array}$ & $\begin{array}{c}221 \pm 2.90 \mathrm{a} \\
(-40.5)\end{array}$ & $\begin{array}{c}1.85 \pm 0.04 a \\
(-33.4)\end{array}$ & $\begin{array}{c}0.94 \pm 0.02 \mathrm{a} \\
(-44.8)\end{array}$ & $\begin{array}{c}0.79 \pm 0.02 \mathrm{a} \\
(-65.5)\end{array}$ & $\begin{array}{c}14.13 \pm 0.17 a \\
(-32.3)\end{array}$ \\
\hline IAA & $\begin{array}{c}2.41 \pm 0.02 \mathrm{~b} \\
(14.2)\end{array}$ & $\begin{array}{c}209 \pm 2.02 b \\
(14.2)\end{array}$ & $\begin{array}{c}3.55 \pm 0.02 b \\
(6.1)\end{array}$ & $\begin{array}{c}583 \pm 3.18 b \\
(9.8)\end{array}$ & $\begin{array}{c}3.94 \pm 0.02 b \\
(14.9)\end{array}$ & $\begin{array}{c}392 \pm 2.64 b \\
(5.3)\end{array}$ & $\begin{array}{c}4.38 \pm 0.03 b \\
(57.7)\end{array}$ & $\begin{array}{c}2.13 \pm 0.04 \mathrm{~b} \\
(25.2)\end{array}$ & $\begin{array}{c}3.41 \pm 0.02 b \\
(48.4)\end{array}$ & $\begin{array}{c}22.76 \pm 0.14 b \\
(8.9)\end{array}$ \\
\hline $\mathrm{S}+\mathrm{IAA}$ & $\begin{array}{c}1.64 \pm 0.02 \mathrm{c} \\
(-22.3)\end{array}$ & $\begin{array}{c}132 \pm 2.33 c \\
(-27.9)\end{array}$ & $\begin{array}{c}2.95 \pm 0.03 c \\
(-11.6)\end{array}$ & $\begin{array}{c}387 \pm 2.33 c \\
(-27.0)\end{array}$ & $\begin{array}{c}2.85 \pm 0.01 c \\
(-16.7)\end{array}$ & $\begin{array}{c}273 \pm 2.51 c \\
(-26.6)\end{array}$ & $\begin{array}{c}2.53 \pm 0.03 c \\
(-8.9)\end{array}$ & $\begin{array}{c}1.50 \pm 0.01 \mathrm{c} \\
(-11.5)\end{array}$ & $\begin{array}{c}2.06 \pm 0.03 c \\
(-10.4)\end{array}$ & $\begin{array}{c}18.43 \pm 0.26 c \\
(-11.8)\end{array}$ \\
\hline BA & $\begin{array}{c}2.35 \pm 0.02 b \\
(11.7)\end{array}$ & $\begin{array}{c}196 \pm 3.18 \mathrm{~d} \\
(6.9)\end{array}$ & $\begin{array}{c}3.49 \pm 0.01 b \\
(4.3)\end{array}$ & $\begin{array}{c}575 \pm 3.18 b \\
(8.3)\end{array}$ & $\begin{array}{c}3.84 \pm 0.02 b \\
(12.1)\end{array}$ & $\begin{array}{c}381 \pm 4.04 \mathrm{bd} \\
(2.3)\end{array}$ & $\begin{array}{c}4.36 \pm 0.03 b \\
(56.9)\end{array}$ & $\begin{array}{c}2.12 \pm 0.04 \mathrm{~b} \\
(24.4)\end{array}$ & $\begin{array}{c}3.42 \pm 0.01 b \\
(48.8)\end{array}$ & $\begin{array}{c}22.46 \pm 0.27 \mathrm{~b} \\
(7.5)\end{array}$ \\
\hline$S+B A$ & $\begin{array}{c}1.54 \pm 0.02 \mathrm{c} \\
(-26.8)\end{array}$ & $\begin{array}{c}124 \pm 2.33 c \\
(-32.1)\end{array}$ & $\begin{array}{c}2.90 \pm 0.02 \mathrm{c} \\
(-13.1)\end{array}$ & $\begin{array}{c}375 \pm 3.21 c \\
(-29.4)\end{array}$ & $\begin{array}{c}2.78 \pm 0.03 c \\
(-18.7)\end{array}$ & $\begin{array}{c}270 \pm 2.33 c \\
(-27.3)\end{array}$ & $\begin{array}{c}2.46 \pm 0.03 c \\
(-11.3)\end{array}$ & $\begin{array}{c}1.54 \pm 0.07 \mathrm{c} \\
(-9.3)\end{array}$ & $\begin{array}{c}1.99 \pm 0.03 c \\
(-13.4)\end{array}$ & $\begin{array}{c}18.03 \pm 0.20 c \\
(-13.7)\end{array}$ \\
\hline
\end{tabular}

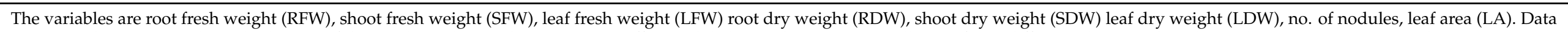

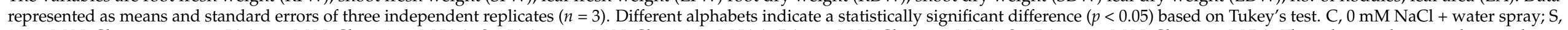

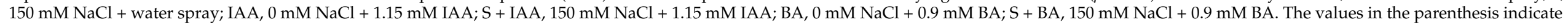
percentage $(\%)$ change versus control and the '-' sign indicates the decrease. 


\subsection{Applications IAA or BA Changed the Accumulation of Osmoprotectants Level}

Salinity stress significantly reduced the SS and SP contents in the root, stem, leaf, and seed of faba bean plants versus control plants (Figure 1A-H). However, the SS and $\mathrm{SP}$ contents were significantly higher in the root, stem, and leaf in ' $\mathrm{S}+\mathrm{IAA}^{\prime}$ ' and ' $\mathrm{S}+\mathrm{BA}^{\prime}$ treatments than the only salt-stressed plants (Figure 1A-H). In seed, ' $\mathrm{S}+\mathrm{IAA}^{\prime}$ and ' $\mathrm{S}+\mathrm{BA}^{\prime}$ treatments increased significant SS content, but not SP content compared to only saltstressed plants (Figure 1D-H). Among the two treatments, 'S + IAA' and 'S + BA', there were no significant differences in SS and SP contents between the organs except for seed and stem; where 'S + IAA' induced plants were higher than the 'S + BA' (Figure 1A-H). Moreover, 'IAA' and 'BA' plants also showed significantly higher SP and SS contents in almost all studied plant organs except in seed against control (Figure 1A-H). In contrast, the results showed the opposite pattern in the case of FAA and proline accumulation, where the contents of FAA and proline accumulation increased in salt-stressed plants than in the control plants (Figure 1I-P). However, the 'S + IAA' and 'S + BA' plants showed a further significant increase of FAA content than the salt-stressed and control plants (Figure 1I-L), whereas there was a significant increase of proline content than salt-stressed plants in almost all organs except seed (Figure 1M-P). Only 'IAA' and 'BA' plants also exhibited significantly higher FAA contents in all plant organs, whereas proline significantly decreased only in the stem and leaf of faba bean compared to the control plants (Figure 1I-P).

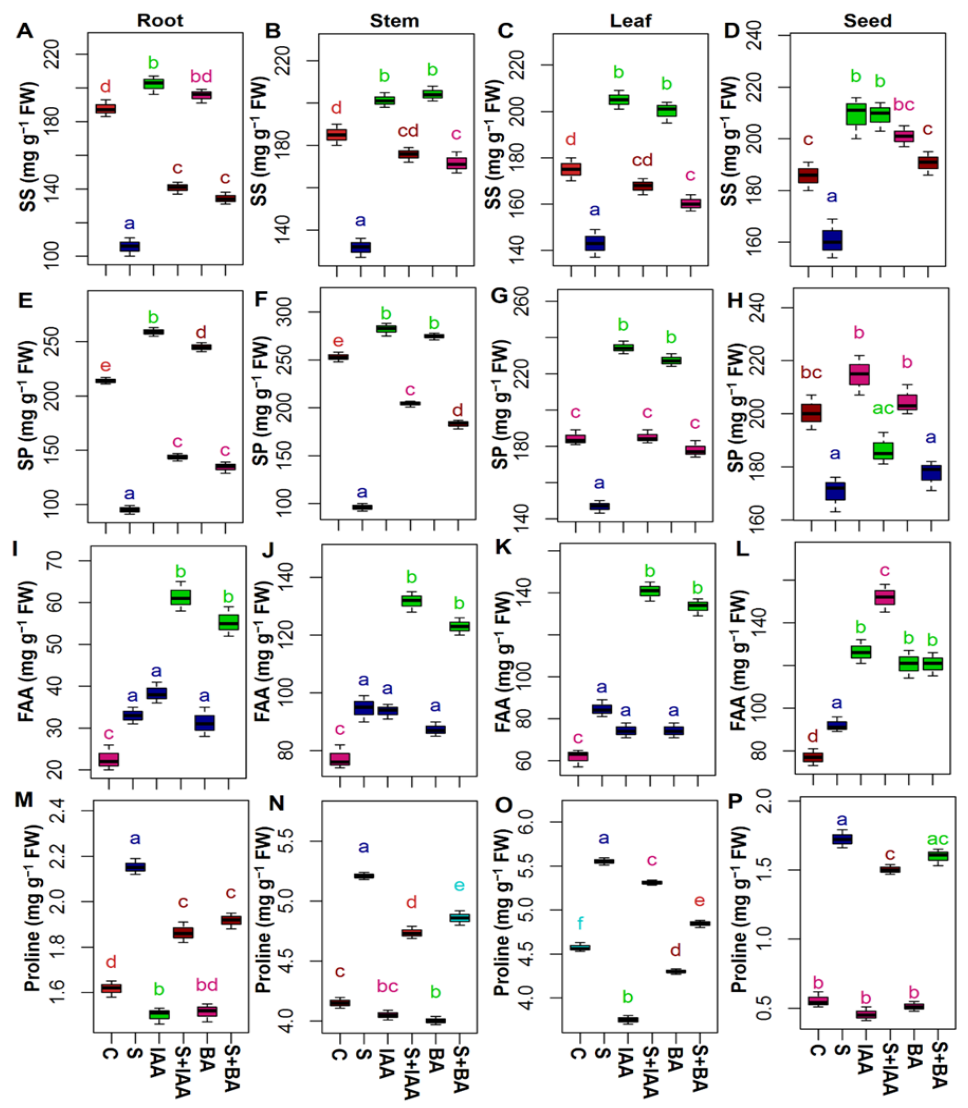

Figure 1. Effects of indole-3-acetic acid (IAA) or 6-benzyladenine (BA) foliar applications on various osmolytes in different organs of faba bean plants grown under normal and saline conditions. (A-D) soluble sugar (SS) contents in root, stem, leaf, and seed; (E-H) soluble protein (SP) content in root, stem, leaf, and seed; (I-L) free amino acid (FAA) content in root, stem, leaf, and seed; (M-P) proline content in root, stem, leaf, and seed. Each boxplot represents values of three independent replicates $(n=3)$. Different alphabets indicate a statistically significant difference $(p<0.05)$ by Tukey's test. C, $0 \mathrm{mM} \mathrm{NaCl}+$ water spray; $S, 150 \mathrm{mM} \mathrm{NaCl}+$ water spray; IAA, $0 \mathrm{mM}$ $\mathrm{NaCl}+1.15 \mathrm{mM}$ IAA; $\mathrm{S}+\mathrm{IAA}, 150 \mathrm{mM} \mathrm{NaCl}+1.15 \mathrm{mM}$ IAA; BA, $0 \mathrm{mM} \mathrm{NaCl}+0.9 \mathrm{mM}$ BA; $\mathrm{S}+\mathrm{BA}$, $150 \mathrm{mM} \mathrm{NaCl}+0.9 \mathrm{mM}$ BA. 


\subsection{Exogenous IAA or BA Regulated the Mineral Homeostasis under Salt Stress}

Salinity significantly enhanced the $\mathrm{Na}^{+}$content and decreased $\mathrm{K}^{+}, \mathrm{Ca}^{2+}$, and $\mathrm{Mg}^{2+}$ contents in root, stem, leaf, and seed of faba bean plants versus non-stress plants (Figure 2A-P). However, foliar application of IAA or BA in 'S + IAA' and 'S + BA' plants significantly diminished the accumulation of $\mathrm{Na}^{+}$content and improved the accumulation of $\mathrm{K}^{+}, \mathrm{Ca}^{2+}$, and $\mathrm{Mg}^{2+}$ contents in root, stem, leaf, and seed compared to only salt-stressed faba bean plants (Figure $2 \mathrm{~A}-\mathrm{P}$ ). Besides, $\mathrm{K}^{+}, \mathrm{Ca}^{2+}$, and $\mathrm{Mg}^{2+}$ contents also significantly increased in 'IAA' and 'BA' plants against the control plants (Figure 2E-P). The 'S + BA' plants showed significantly higher accumulation of $\mathrm{Na}^{+}$in root, leaf, and seed than 'S + IAA' plants (Figure 2A,C,D).

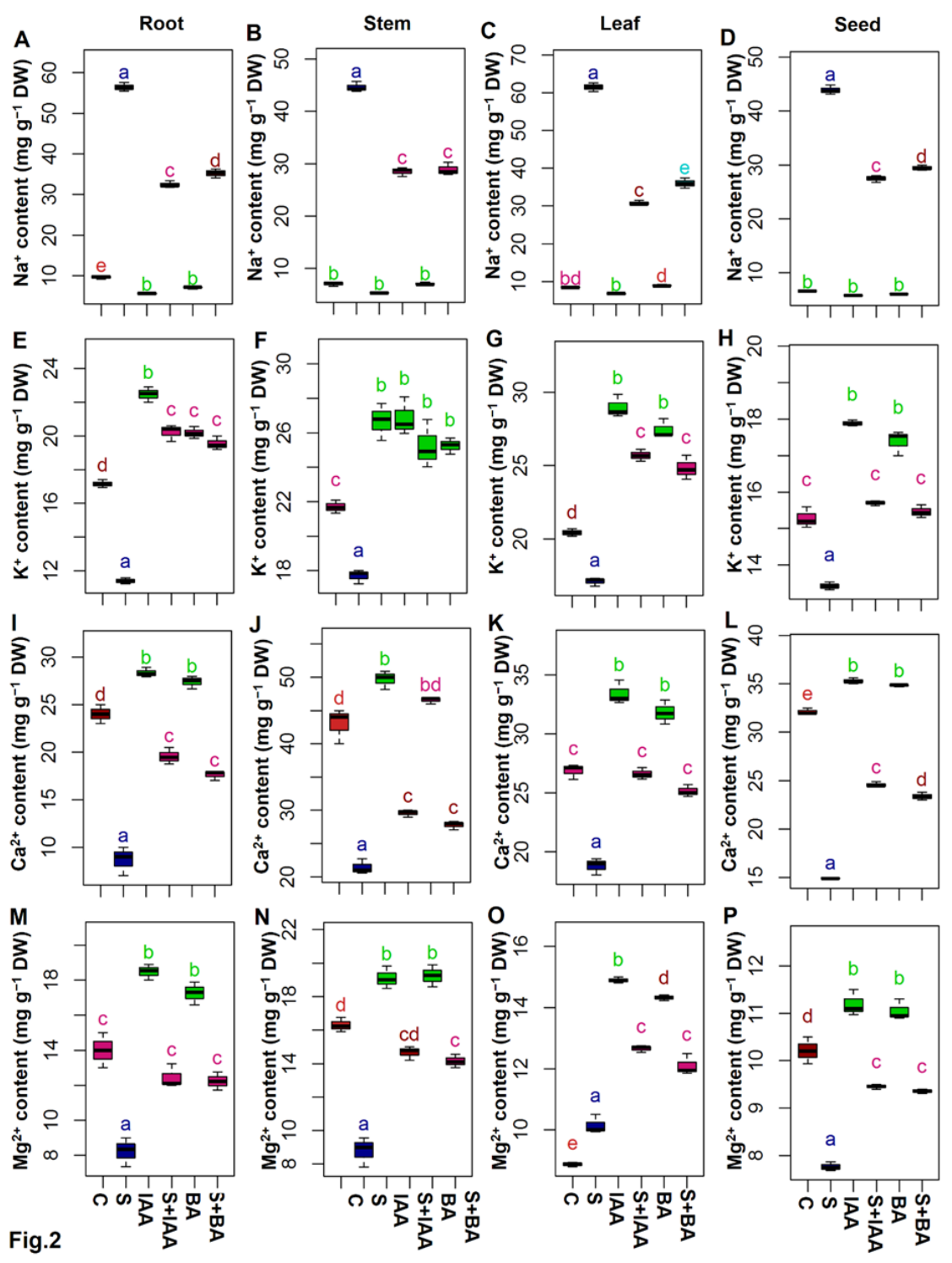

Figure 2. Effects of indole-3-acetic acid (IAA) or 6-benzyladenine (BA) foliar applications on various ion accumulation in different organs of faba bean plants grown under non stress and saline conditions. (A-D) $\mathrm{Na}^{+}$contents in root, stem, leaf, and seed; $(\mathbf{E}-\mathbf{H}) \mathrm{K}^{+}$content in root, stem, leaf, and seed; (I-L) $\mathrm{Ca}^{2+}$ content in root, stem, leaf, and seed; (M-P) $\mathrm{Mg}^{2+}$ in root, stem, leaf, and seed. Each boxplot represents values of three independent replicates $(n=3)$. Different letters above the bars indicate a statistically significant difference $(p<0.05)$ by Tukey's test. C, $0 \mathrm{mM} \mathrm{NaCl}+$ water spray; $\mathrm{S}$, $150 \mathrm{mM} \mathrm{NaCl}$ + water spray; IAA, $0 \mathrm{mM} \mathrm{NaCl}+1.15 \mathrm{mM}$ IAA; $\mathrm{S}+\mathrm{IAA}, 150 \mathrm{mM} \mathrm{NaCl}+1.15 \mathrm{mM}$ IAA; BA, $0 \mathrm{mM} \mathrm{NaCl}+0.9 \mathrm{mM}$ BA; $\mathrm{S}+\mathrm{BA}, 150 \mathrm{mM} \mathrm{NaCl}+0.9 \mathrm{mM}$ BA. 


\subsection{Applications of IAA or BA Prevented Lipid Peroxidation by Enhancing Antioxidant Enzymes}

We determined the content of MDA, and activities of SOD, CAT, POD, and APX of faba bean leaves to appraise their roles of IAA or BA on ROS detoxifications and membrane protection under salinity conditions. In salt-stressed faba bean plants, the MDA content and SOD, CAT, POD, and APX activities increased significantly over the control plants (Figure 3A-E). Further foliar application of IAA or BA significantly increased the activities of antioxidant enzymes such as SOD, CAT, POD, and APX in 'S + IAA' and 'S +BA' plants compared to the only salt-stressed plants (Figure 3B-E). At the same time, the MDA content significantly decreased in 'S + IAA' and 'S +BA' faba bean plants compared to the only salt-stressed plants (Figure 3A). Between the two treatment, ' $\mathrm{S}+\mathrm{IAA}^{\prime}$ treatment showed a higher effect on MDA decrement than ' $\mathrm{S}+\mathrm{BA}^{\prime}$ treatment (Figure $3 \mathrm{~A}$ ) and a higher increment of CAT activity (Figure 3C).
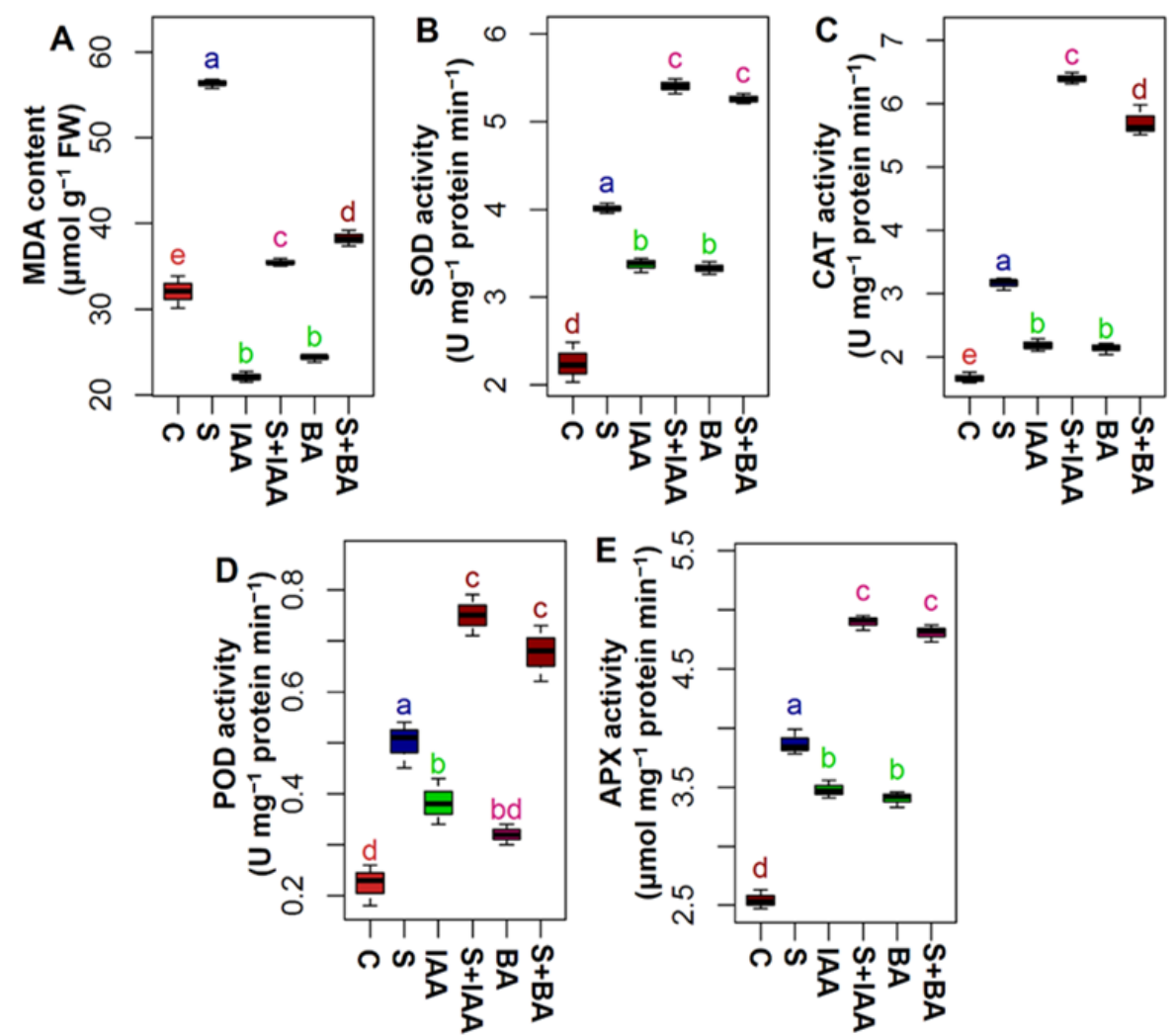

Figure 3. Effects of foliar-applied indole-3-acetic acid (IAA) or 6-benzyladenine (BA) on (A) malondialdehyde (MDA) content, (B) SOD (superoxide dismutase) activity, (C) CAT (catalase) activity, (D) POD (peroxidase) activity, and (E) APX (ascorbate peroxidase) activity in faba bean plants grown under normal and saline conditions. Each boxplot represents values of three independent replicates $(n=3)$. Different alphabets indicate a statistically significant difference $(p<0.05)$ by Tukey's test. $C$, $0 \mathrm{mM} \mathrm{NaCl}$ + water spray; $\mathrm{S}, 150 \mathrm{mM} \mathrm{NaCl}$ + water spray; IAA, $0 \mathrm{mM} \mathrm{NaCl}+1.15 \mathrm{mM}$ IAA; $\mathrm{S}+\mathrm{IAA}$, $150 \mathrm{mM} \mathrm{NaCl}+1.15 \mathrm{mM}$ IAA; BA, $0 \mathrm{mM} \mathrm{NaCl}+0.9 \mathrm{mM}$ BA; $\mathrm{S}+\mathrm{BA}, 150 \mathrm{mM} \mathrm{NaCl}+0.9 \mathrm{mM}$ BA.

\subsection{Visualization and Understanding of Treatment-Variable Relationship through Hierarchical} Clustering and PCA

To imagine all findings together, we generated a clustered heatmap with a color intensity that also classified variables in four clusters (I-IV) (Figure 4A). Clusters-I and -II mainly represent all growth and yield traits, $\mathrm{K}+, \mathrm{Ca}^{2+}, \mathrm{Mg}^{2+}$, SS, SP contents of root, stem, leaf, and seed and FAA content of the seed. All those variables of cluster-I and -II showed the lowest values in 'S' treatment and increasing trend under 'S + IAA' and 'S + BA' treatments (Figure 4A). Cluster-III represents $\mathrm{Na}^{+}$and proline contents of root, stem, leaf, and seed and MDA content, which were highest in the ' $\mathrm{S}$ ' treatment and 
showed a decreasing trend under S + IAA' and 'S + BA' treatments (Figure 4A). This means that supplementation of IAA or BA by foliar spray to salt-stressed plants partially recovered those variables. Cluster-IV represents the activities of enzymatic antioxidants such as SOD, POD, APX, CAT, and FAA in root, stem, and leaf (Figure 4A). Variables of Cluster-IV showed an increasing trend in 'S + IAA' and 'S + BA' treatments in comparison with that in ' $\mathrm{S}$ ' and ' $\mathrm{C}$ ' plants (Figure 4A). Afterward, PCA was performed to grasp the association of all clusters of variables with different treatments. The PCA biplot revealed that 'IAA' and 'BA' treatments were strongly associated with variables of Cluster-II, while 'S + IAA' was strongly associated with Cluster-IV and moderately associated with Cluster-I (Figure 4B). Moreover, 'S + BA' treatment was moderately associated with Cluster-III and -IV (Figure 4B). Only salt-stress treatment, ' $\mathrm{S}$ ' treatment, was strongly associated with Cluster-III (Figure 4B).

A
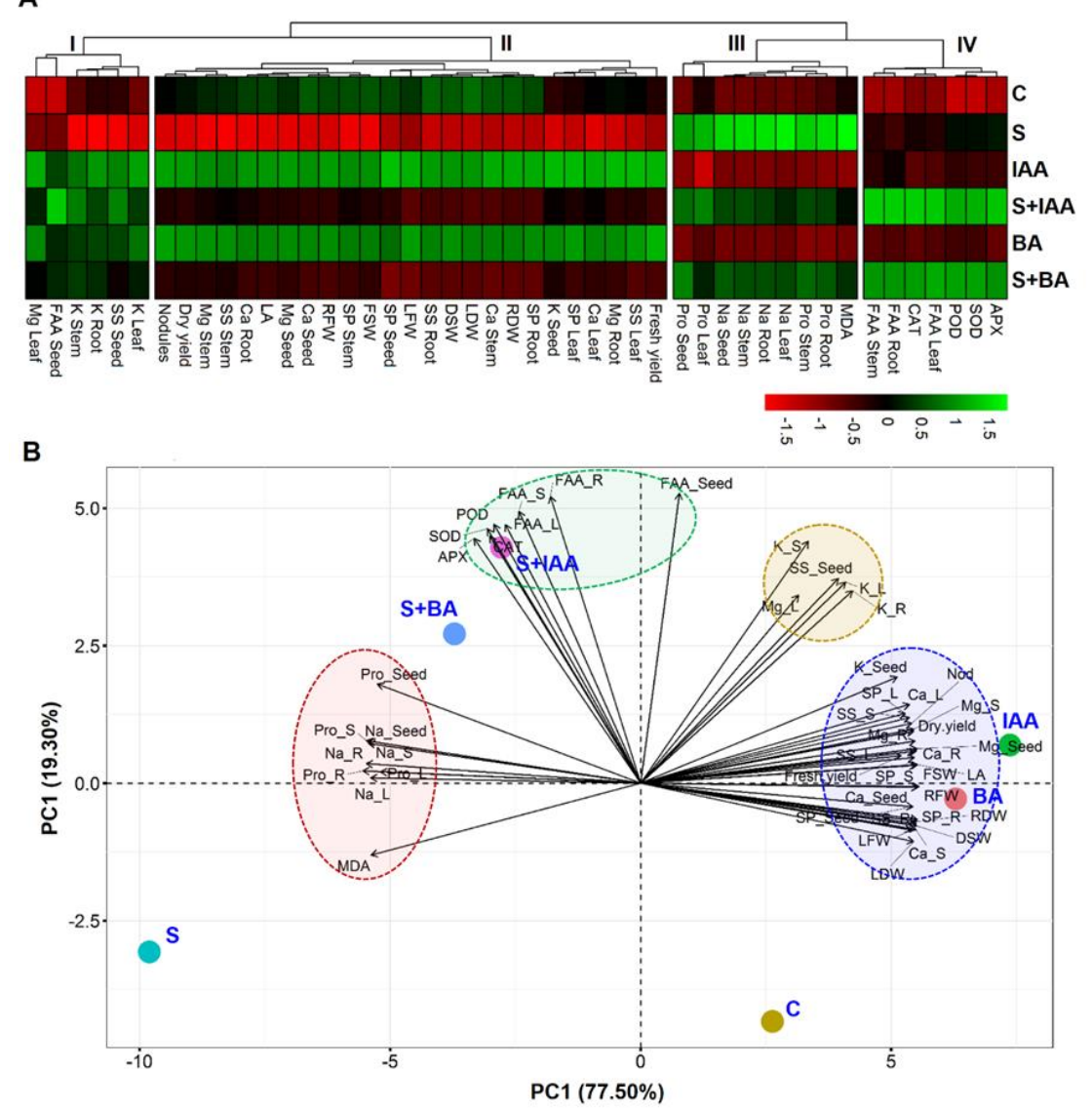

Figure 4. Hierarchical clustered heatmap and principal component analysis (PCA) were performed to understand the relationship between the treatment variable. (A) Different parameters mean values were normalized and clustered. Color scale stipulates the changing trend of different parameters of normalized mean values under different treatment conditions. (B) PCA was used to analyze the entire data. The central point lines of biplot indicate positive or negative correlations of different variables; where their closeness indicates correlation strength with a particular treatment. The variables are root fresh weight (RFW), shoot fresh weight (SFW), leaf fresh weight (LFW) root dry weight (RDW), shoot dry weight (SDW), leaf dry weight (LDW), no. of nodules (Nodules), leaf area (LA), soluble sugars (SS), soluble proteins (SP), free amino acid (FAA), proline (Pro), malondialdehyde content (MDA), superoxide dismutase (SOD) activity, catalase (CAT) activity, peroxidase (POD) activity, ascorbate peroxidase (APX) activity. The notation with different parameters '_S', '_R' and '_L' indicate stem, root and leaf, respectively. $\mathrm{C}, 0 \mathrm{mM} \mathrm{NaCl}$ + water spray; $\mathrm{S}, 150 \mathrm{mM} \mathrm{NaCl}+$ water spray; IAA, $0 \mathrm{mM}$ $\mathrm{NaCl}+1.15$ mM IAA; $\mathrm{S}+\mathrm{IAA}, 150 \mathrm{mM} \mathrm{NaCl}+1.15 \mathrm{mM}$ IAA; BA, $0 \mathrm{mM} \mathrm{NaCl}+0.9 \mathrm{mM}$ BA; S + BA, $150 \mathrm{mM} \mathrm{NaCl}+0.9 \mathrm{mM}$ BA. 


\subsection{Foliar Application of IAA or BA Changes Protein Expression Pattern under Salt Stress}

The alternation in protein banding pattern during salt-stress alone or combination with IAA or BA treatments produced new polypeptide bands and disappeared from other polypeptide bands (Figure 5, Table S1 and Figure S1). The data showed the appearance and disappearance of different bands with different molecular weights from $221 \mathrm{kDa}$ to $15 \mathrm{kDa}$. Salinity stress at $150 \mathrm{mM} \mathrm{NaCl}$ expressed new polypeptide bands of molecular weights, 213, $137,118,85$, and $16 \mathrm{kDa}$ compared with the non-saline condition (Figure 5 and Table S1). In contrast, bands of molecular weights 150, 126, 115, 109, 108, 104, 92, 91, 88, 70, 50, 39, 33,22 , and $18 \mathrm{kDa}$ appeared under the non-saline condition but is absent under salt stress condition. Applications of IAA or BA in faba bean plants produced nine and eight new bands, respectively, where five bands at the same molecular weights, except IAA $(200,84$, 83, and $16 \mathrm{kDa}$ ) and BA $(163,137$, and $135 \mathrm{kDa})$ (Figures 5 and S1, Table S1 ). While faba bean plants grown under $150 \mathrm{mM} \mathrm{NaCl}$ of salinity and treated with IAA or BA showed a new band at 12 and 11 with the same molecular weight of 217, 208, 132, 130, 85, 84, 83, 17, $16,15 \mathrm{kDa}$ except for IAA (204 and $115 \mathrm{kDa}$ ) and BA (213 kDa), respectively. Moreover, our results also showed a new band of $85 \mathrm{kDa}$ under stressed conditions and application of IAA or BA in non-stressed conditions (Figures 5 and S1, Table S1).
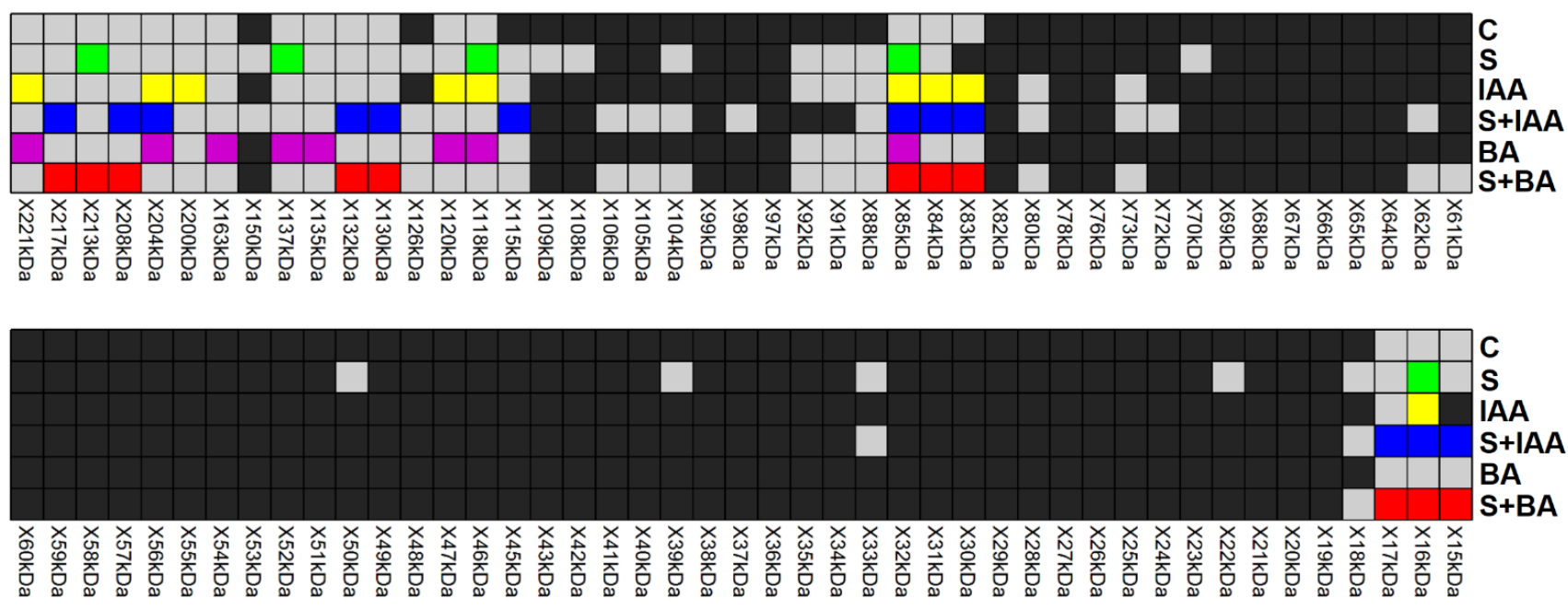

\begin{tabular}{|l|l|l|l|l|l|l|}
\hline Bands & C & S & IAA & S+IAA & BA & S+BA \\
\hline Number of bands & 71 & 59 & 75 & 69 & 74 & 67 \\
\hline Number of new bands & & $\mathbf{5}$ & $\mathbf{9}$ & $\mathbf{1 2}$ & $\mathbf{8}$ & $\mathbf{1 1}$ \\
\hline
\end{tabular}

New bands compared to control

Band appears No band appears

Figure 5. Protein patterns of faba bean plants in response to salinity stress alone or in combination with indole-3acetic acid (IAA) or 6-benzyladenine (BA) foliar spray. C, $0 \mathrm{mM} \mathrm{NaCl}+$ water spray; $\mathrm{S}, 150 \mathrm{mM} \mathrm{NaCl}+\mathrm{water}$ spray; IAA, $0 \mathrm{mM} \mathrm{NaCl}+1.15$ mM IAA; S + IAA, $150 \mathrm{mM} \mathrm{NaCl}+1.15 \mathrm{mM}$ IAA; BA, $0 \mathrm{mM} \mathrm{NaCl}+0.9 \mathrm{mM}$ BA; S + BA, $150 \mathrm{mM} \mathrm{NaCl}+0.9 \mathrm{mM}$ BA. The values followed by $\mathrm{X}$ indicates the molecular weight of protein in kilodalton (kDa) unit.

\section{Discussion}

Plants exposed to salinity stress exhibited a reduction in growth and yield potential $[31,55,56]$. However, foliar applications of IAA or BA mitigated the negative effects of salinity, as evidenced by the improvements of root, shoot, and leaf weights and leaf area of faba bean (Table 1). To clarify the fundamental mechanisms of exogenous IAA- and BA-mediated salinity stress alleviation, we examined several biochemical features that could be used to improve faba bean endurance under salinity stress conditions. 
In our study, salinity had severe negative effects on faba bean plants, as manifested by the significant reductions of growth and biomass when compared to non-stressed plants (Table 1). This growth reduction eventually contributed to the significant yield loss of faba bean plants (Table 1). Similar findings were also reported in other legumes like Vigna radiata [13], Cicer arietinum [57], Lupinus albus [58], and Vicia faba [59] under salt-stress condition. On the other hand, foliar applications of IAA resuscitated the growth performance of saltstressed faba bean plants as shown by improved morphological attributes (Table 1). Similar positive effects of IAA were also observed in different crops under stress conditions such as under salt stress in Zea mays [28], Oryza sativa [60], Solanum lycopersicum [27], Solanum tuberosum [61], Carica papaya [62], and under drought stress in Triticum aestioum [63] and Trifolium repens [64]. Auxin acts as a driver of several morpho-physiological processes [65]. Under salt stress conditions, auxin levels and transporter expression were decreased, thereby the plant cannot translocate auxins [66]. However, the foliar application of IAA might help to recover the levels of auxin in faba bean plants. Application of BA has also been proven as a promising tool in the alleviation of the adverse effects of the salt stress (i.e., leaf senescence and developmental or physiological damage) in several crops such as Solanum melongena, Triticum aestivum, Lolium perenne, and Jasminum nudiflorum [34,67-69]. In agreement with these reports, in our study, BA application also enhanced the growth of faba bean under salt stress conditions (Table 1). Here, both 'S + IAA' and 'S + BA' plants showed a prominent increase in root FW and DW, number of nodules, and leaf area relative to only salt-stressed plants (Table 1). This above-mentioned result indicates that the foliar spraying of IAA or BA assisted faba bean plants to maintain better root and leaf growth. Subsequently, the better root growth facilitated more moisture and nutrient uptake from the soil, the higher nodulation helped plants to fix more $\mathrm{N}_{2}$ from the atmosphere, and the larger leaf area ensures better photosynthesis. These beneficial outcomes ultimately improved the growth-related parameters and biomass production of faba bean plants under salinity stress conditions (Table 1). The PCA showed a relatively stronger association of 'S + IAA' and 'S + BA' plants with growth and yield traits than the 'S' plants, which also clearly indicated that IAA- or BA-treatment effectively enhanced salinity stress tolerance in faba bean plants (Figure 4B).

Plants were often subjected to osmotic stress as a result of salinity, and to combat this stress, plants produced and accumulated a variety of osmolytes in their cells such as proline, SS, SP, and FAA [70,71]. Thus, the accumulation of osmolytes like proline, SS, SP, and FAA plays an important role in maintaining water balance and osmotic potential in plants [72,73]. In our study, salinity induced a significant increase in the accumulation of proline and FAA contents and a decrease in SS and SP contents in all organs of faba bean plants (Figure 1). In agreement with our findings, [13] reported an increased proline and FAA contents in salt-stressed Vigna radiata, and [74] showed an increased proline and FAA contents and decreased SP content in saline-alkaline-stressed Cynara scolymus plants. Our findings also showed that the levels of proline accumulation in faba bean corresponded to the levels of cellular osmotic imbalance. However, in both the 'S + IAA' and 'S + BA' faba bean plants, the amount of proline accumulation was significantly reduced whereas the levels of SS, SP, and FAA were significantly enhanced (Figure 1), indicating that IAA or BA treatments can reduce the severity of salt-induced osmotic imbalance in faba bean plants. Moreover, there was an increase in SP, SS, and FAA contents in 'S + IAA' and 'S + BA' plants (Figure 1A-L), indicating that these plants had a better metabolic condition than only saltstressed plants. Aside from osmoprotection, the SS, SP, and FAA can play several vital roles in plant stress tolerance including cellular signaling, cell membrane defense, secondary metabolite biosynthesis, and organic nitrogen and carbon supply $[75,76]$. Overall, our results suggest that the increased accumulation of SP, SS, and FAA in different organs of faba bean ensure elevated water status in root, stem, and leaves of ' $\mathrm{S}+\mathrm{IAA}^{\prime}$ and 'S + BA' plants and prevents the excessive accumulation of proline (Figure 1). The PCA also validated our results that proline content showed a stronger association with ' $S$ ' plants than 'S + IAA' and 'S + BA' plants (Figure 4B). It should be noted that IAA- and BA-mediated 
improvements of osmolyte accumulation and better osmotic adjustment have also been recorded in Glycine max under water stress [77], Triticum aestivum under drought stress [63], Solanum melongena under salt stress [34], and Zea mays under boron stress [78].

The poor growth performance of salinized plants was closely correlated with ionic toxicity because of an overloaded accumulation of toxic $\mathrm{Na}^{+}$in the cells, and a substantial decrease in beneficial ions, namely $\mathrm{K}^{+}, \mathrm{Ca}^{2+}$, and $\mathrm{Mg}^{2+}$ contents in all organs of faba bean (Figure 2A-D), which might have occurred due to the damages of the cell membrane, ion leakage, and disturbance in essential ion uptakes [31]. Our results are also supported by different studies under salt stress in different crops such as Oryza sativa $[79,80]$ and Salicornia europaea [81]. The PCA biplot also showed positive correlations between salinity treatment and $\mathrm{Na}^{+}$contents in different plant parts (Figure 4B). Supplementing salt-stressed faba bean plants with IAA or BA increased accumulation of $\mathrm{K}^{+}, \mathrm{Ca}^{2+}$, and $\mathrm{Mg}^{2+}$ contents while decreased $\mathrm{Na}^{+}$content in all plant organs (Figure 2), which supported a piece of indirect, but strong evidence that IAA or BA treatments helped in effective removal of $\mathrm{Na}^{+}$into the vacuoles and abundance of nutrients, especially $\mathrm{K}^{+}$, as further beginning by enhancing leaf succulence, increasing the plant's ability to survive as a consequence of improved cell membrane integrity, increased nutritional balance, and improved physical appearance of salt-stressed faba bean plants $[10,82]$. Similar results were noticed in several experiments that reported the functions of exogenous IAA in boron-stressed Zea mays [78] and salt-stressed Zea mays [28], and of exogenous BA in salt-stressed Lolium perenne cv. Pinnacle [68] and boron-stressed Zea mays [78] plants. Interestingly, 'S + BA' plants showed less accumulation of $\mathrm{Ca}^{2+}$ content in the seed, which may be due to the high accumulation of $\mathrm{Na}^{+}$in the seed, whereas root and leaf perhaps recover the adverse effects of $\mathrm{Na}^{+}$, but ultimately seed was affected (Figure 2).

Our findings showed that faba bean plants exposed to $\mathrm{NaCl}$-induced stress had significantly higher MDA content than the control plants (Figure 3A). It is well known that when plants are exposed to salt, they accumulate an excessive amount of $\mathrm{Na}^{+}$, which disrupts the plant metabolism system and places significant stress on the plants, causing oxidative stress to the plant's cellular components [83,84]. The higher levels of ROS directly deteriorate the lipid membranes of the plants, which accelerates the accumulation of MDA, as a result, lipid membrane peroxidation occurs, acting as a positive indicator of oxidative damage [85]. We found that salt-stressed plants had higher MDA levels than non-stressed plants (Figure 3A) and similar results were also obtained by [86] on Cicer arietinum plants and by [59] on Vicia faba plants. More importantly, we obtained that exogenously IAA or BA reduced MDA accumulations and improved membrane integrity in faba bean plants grown under salt stress (Figure 3A). These results suggest that IAA or BA might recover the adverse effect of faba bean plants from salt stress by reducing oxidative damage and contributed to better salinity tolerance. Salt stress also increases the enzymatic antioxidant activities like APX, SOD, POD, and CAT significantly in faba bean plants (Figure 3B-E). Upregulation of the oxidative defense system has also been found in different crops under different abiotic stresses, for example, Brassica oleracea var. botrytis [87], Brassica napus [88], Zea may [84], Oryza sativa [89], whereas opposite findings were reported in Pisum sativum [90] and Oryza sativa [45]. However, our results indicated that foliar application of IAA or BA significantly upregulated the activities of all studied antioxidant enzymes in the faba bean plants under salt stress (Figure 3B-E), which indicates that these ROS scavenging enzymes defend the faba bean plant from salt stress by catalyzing the $\mathrm{O}_{2}{ }^{\bullet-}$ to $\mathrm{O}_{2}$ and $\mathrm{H}_{2} \mathrm{O}_{2}$, and $\mathrm{H}_{2} \mathrm{O}_{2}$ to $\mathrm{H}_{2} \mathrm{O}$ in the cell and increasing the oxidative stress tolerance. This is supported by what has been earlier observed by [91] under boron stress on Triticum aestivum, Zea mays [78], and under salt stress in Nigella sativa [92]. Accordingly, our PCA results also demonstrated that 'S + IAA' and 'S + BA' faba bean plants showed a stronger and positive correlation with enzymatic antioxidants whereas ' $\mathrm{S}$ ' plants showed a stronger and positive correlation with MDA content (Figure 4B). Furthermore, the 'S + IAA' plants showed a relatively stronger positive correlation with antioxidant enzymes than 
'S + BA' plants (Figure 4B), indicating that IAA had a better influence on the elevation of antioxidant enzymes than BA.

The protein pattern expression indicated the ability of a plant's tolerance to salt stress and specific polypeptide was synthesized by plants under salt stress for salt adaptation [93]. Our study also showed that during salinity stress, faba bean plants synthesized a various number of new stress-specific proteins under salt stress for better salt adaptation (Figure 5). Several studies have already established that under stress situations, different plants produced several new specific proteins (i.e., in rice leaf [94] and faba bean seedlings [95]). Under different abiotic stresses like heat stresses, the plant changes the protein pattern and produces a new protein band, which can be confirmed by electrophoretic analysis [96]. The protein related to salt stress is a positive indicator of salinity stress compared to nonstressed plants [97]. Finally, our results showed both salinity stress and foliar application of IAA or BA, creating a major change in the plant protein profile with different intensities. Faba bean plants showed better adaptation and increased saline tolerance, which was confirmed by the exhibited new protein profiles under both saline and treated with IAA or BA conditions. The IAA applied plants produced more new protein bands than BA (Figure 5 and Table S1), indicating that IAA has more ability to rescue the plants from salt stress and adapt to the salt stress condition.

\section{Conclusions}

In conclusion, we provided strong evidence that applications of IAA or BA on saltstressed faba bean plants successfully alleviated salt stress-induced effects by reducing the accumulation of $\mathrm{Na}^{+}$that re-establishes mineral homeostasis, enhancing antioxidant enzymes that reduce oxidative stress, and maintaining osmotic adjustment via osmolyte upregulation. The protein profile also indicated the disappearance of polypeptide bands in response to stress and foliar applications of IAA or BA showed a new protein band and newly expressed protein that might diminish the adverse effects of salt stress and increase better adaptation to faba bean plants. Both plant hormones showed similar effects on the growth and yield improvement of faba bean plants. IAA has shown more ability to reduce the accumulation of $\mathrm{Na}^{+}$and MDA content and to increase the CAT activity and appearance of a newer band than the BA. However, future studies should be required at the root level on large scale using different concentrations of IAA or BA applications to a wide range of crop species to find out the beneficial roles of IAA or BA in the management of salinity stress under different salinity stress regions worldwide.

Supplementary Materials: The following are available online at https:/ / www.mdpi.com/article/10 .3390 /agronomy11040790/s1, Table S1: Protein patterns of faba bean plants in response to salinity stress alone or in combination with IAA or BA foliar spray. Figure S1: Coomassie blue-stained SDS polyacrylamide gel of polpeptide of faba bean plants in response to salinity alone or in combination with $1.15 \mathrm{mM}$ IAA or $0.9 \mathrm{mM}$ BA hormones.

Author Contributions: Conceptualization, A.A.H.A.L.; Data curation, A.A.H.A.L.; Formal analysis, M.T.-U.-A.; Funding acquisition, A.A.H.A.L.; Investigation, M.T.-U.-A., A.A. and A.A.H.A.L.; Methodology, A.A.H.A.L.; Project administration, A.A.H.A.L.; Resources, A.A.H.A.L.; Software, M.T.-U.-A.; Supervision, A.A.H.A.L.; Visualization, M.T.-U.-A.; Roles/Writing一original draft, A.A. and M.T.-U.-A.; Writing-review and editing, M.T.-U.-A. and A.A.H.A.L. All authors have read and agreed to the published version of the manuscript.

Funding: This research was funded by Taif University Researchers Supporting Project number (TURSP-2020/72), Taif University, Taif, Saudi Arabia.

Institutional Review Board Statement: Not applicable.

Informed Consent Statement: Not applicable.

Data Availability Statement: The data supporting the findings of this study are available from the corresponding author upon request.

Conflicts of Interest: The authors declare that there are no conflicts of interest related to this article. 


\section{References}

1. Ahmad, R.; Hussain, S.; Anjum, M.A.; Khalid, M.F.; Saqib, M.; Zakir, I.; Hassan, A.; Fahad, S.; Ahmad, S. Oxidative Stress and Antioxidant Defense Mechanisms in Plants Under Salt Stress. In Plant Abiotic Stress Tolerance; Hasanuzzaman, M., Hakeem, K.R., Nahar, K., Alharby, H.F., Eds.; Springer International Publishing: Cham, Switzerland, 2019; pp. 191-205, ISBN 978-3-030-06117-3.

2. Mbarki, S.; Sytar, O.; Cerda, A.; Zivcak, M.; Rastogi, A.; He, X.; Zoghlami, A.; Abdelly, C.; Brestic, M. Strategies to Mitigate the Salt Stress Effects on Photosynthetic Apparatus and Productivity of Crop Plants. In Salinity Responses and Tolerance in Plants, Volume 1: Targeting Sensory, Transport and Signaling Mechanisms; Kumar, V., Wani, S.H., Suprasanna, P., Tran, L.-S.P., Eds.; Springer International Publishing: Cham, Switzerland, 2018; pp. 85-136, ISBN 978-3-319-75671-4.

3. Abdel Latef, A.A.H.; Abu Alhmad, M.F.; Kordrostami, M.; Abo-Baker, A.-B.A.-E.; Zakir, A. Inoculation with Azospirillum Lipoferum or Azotobacter Chroococcum Reinforces Maize Growth by Improving Physiological Activities Under Saline Conditions. J. Plant Growth Regul. 2020, 39, 1293-1306. [CrossRef]

4. Dash, M.; Panda, S.K. Salt Stress Induced Changes in Growth and Enzyme Activities in Germinating Phaseolus Mungo Seeds. Biol. Plant. 2001, 44, 587-589. [CrossRef]

5. Ashraf, M.Y.; Sarwar, G.; Ashraf, M.; Afaf, R.; Sattar, A. Salinity Induced Changes in $\alpha$-Amylase Activity During Germination and Early Cotton Seedling Growth. Biol. Plant. 2002, 45, 589-591. [CrossRef]

6. Seckin, B.; Sekmen, A.H.; Türkan, İ. An Enhancing Effect of Exogenous Mannitol on the Antioxidant Enzyme Activities in Roots of Wheat Under Salt Stress. J. Plant Growth Regul. 2009, 28, 12-20. [CrossRef]

7. Anuradha, S.; Rao, S.S.R. Effect of Brassinosteroids on Salinity Stress Induced Inhibition of Seed Germination and Seedling Growth of Rice (Oryza Sativa L.). Plant Growth Regul. 2001, 33, 151-153. [CrossRef]

8. Gregory, P.J.; Ismail, S.; Razaq, I.B.; Wahbi, A. Soil Salinity: Current Status and in Depth Analyses for Sustainable Use; Chapter 2; International Atomic Energy Agency: Vienna, Austria, 2018; pp. 4-11.

9. Shahid, S.A.; Zaman, M.; Heng, L. Soil Salinity: Historical Perspectives and a World Overview of the Problem. In Guideline for Salinity Assessment, Mitigation and Adaptation Using Nuclear and Related Techniques; Zaman, M., Shahid, S.A., Heng, L., Eds.; Springer International Publishing: Cham, Switzerland, 2018; pp. 43-53.

10. Shrivastava, P.; Kumar, R. Soil Salinity: A Serious Environmental Issue and Plant Growth Promoting Bacteria as One of the Tools for Its Alleviation. Saudi J. Biol. Sci. 2015, 22, 123-131. [CrossRef]

11. Khan, A.; Khan, A.L.; Muneer, S.; Kim, Y.-H.; Al-Rawahi, A.; Al-Harrasi, A. Silicon and Salinity: Crosstalk in Crop-Mediated Stress Tolerance Mechanisms. Front. Plant Sci. 2019, 10, 1429. [CrossRef] [PubMed]

12. Abdelhamid, M.T.; Shokr, M.M.B.; Bekheta, M.A. Growth, Root Characteristics, and Leaf Nutrients Accumulation of Four Faba Bean (Vicia Faba L.) Cultivars Differing in Their Broomrape Tolerance and the Soil Properties in Relation to Salinity. Commun. Soil Sci. Plant Anal. 2010, 41, 2713-2728. [CrossRef]

13. Rahman, M.M.; Mostofa, M.G.; Rahman, M.A.; Islam, M.R.; Keya, S.S.; Das, A.K.; Miah, M.G.; Kawser, A.Q.M.R.; Ahsan, S.M.; Hashem, A.; et al. Acetic Acid: A Cost-Effective Agent for Mitigation of Seawater-Induced Salt Toxicity in Mung Bean. Sci. Rep. 2019, 9, 15186. [CrossRef] [PubMed]

14. Netondo, G.W.; Onyango, J.C.; Beck, E. Sorghum and Salinity: II. Gas Exchange and Chlorophyll Fluorescence of Sorghum under Salt Stress. Crop Sci. 2004, 44, 806-811. [CrossRef]

15. Khan, W.U.D.; Aziz, T.; Maqsood, M.A.; Farooq, M.; Abdullah, Y.; Ramzani, P.M.A.; Bilal, H.M. Silicon Nutrition Mitigates Salinity Stress in Maize by Modulating Ion Accumulation, Photosynthesis, and Antioxidants. Photosynthetica 2018, 56, 1047-1057. [CrossRef]

16. Shah, F.; Wu, W. Soil and Crop Management Strategies to Ensure Higher Crop Productivity within Sustainable Environments. Sustainability 2019, 11, 1485. [CrossRef]

17. Wang, W.; Xu, Y.; Chen, T.; Xing, L.; Xu, K.; Xu, Y.; Ji, D.; Chen, C.; Xie, C. Regulatory Mechanisms Underlying the Maintenance of Homeostasis in Pyropia Haitanensis under Hypersaline Stress Conditions. Sci. Total Environ. 2019, 662, 168-179. [CrossRef] [PubMed]

18. Khan, N.; Bano, A.; Ali, S.; Babar, M.A. Crosstalk amongst Phytohormones from Planta and PGPR under Biotic and Abiotic Stresses. Plant Growth Regul. 2020, 90, 189-203. [CrossRef]

19. Peleg, Z.; Blumwald, E. Hormone Balance and Abiotic Stress Tolerance in Crop Plants. Curr. Opin. Plant Biol. 2011, 14, 290-295. [CrossRef] [PubMed]

20. Iqbal, N.; Umar, S.; Khan, N.A.; Khan, M.I.R. A New Perspective of Phytohormones in Salinity Tolerance: Regulation of Proline Metabolism. Environ. Exp. Bot. 2014, 100, 34-42. [CrossRef]

21. Khan, M.A.; Gul, B.; Weber, D.J. Action of Plant Growth Regulators and Salinity on Seed Germination of Ceratoides Lanata. Can J. Bot. 2004, 82, 37-42. [CrossRef]

22. Gul, B.; Khan, M.A.; Weber, D.J. Alleviation of Salinity and Dark-Enforced Dormancy in Allenrolfea Occidentalis Seeds under Various Thermoperiods. Aust. J. Bot. 2000, 48, 745-752. [CrossRef]

23. Bielach, A.; Hrtyan, M.; Tognetti, V.B. Plants under Stress: Involvement of Auxin and Cytokinin. Int. J. Mol. Sci. 2017, 18, 1427. [CrossRef]

24. Fahad, S.; Hussain, S.; Matloob, A.; Khan, F.A.; Khaliq, A.; Saud, S.; Hassan, S.; Shan, D.; Khan, F.; Ullah, N.; et al. Phytohormones and Plant Responses to Salinity Stress: A Review. Plant Growth Regul. 2015, 75, 391-404. [CrossRef] 
25. Waheed, A.; Hamid, F.; Ahmad, H.; Abbassi, F.; Aslam, S.; Shah, A.; Ahmad, N.; Naheed, Z.; Ali, H.; Khan, N. Effect of Indole Butyric Acid (IBA) on Early Root Formation (Tomato 'Sahil'Hybrid) Cuttings. J. Mater. Environ. Sci. 2015, 6, $272-279$.

26. Zoubida, B.; Gherroucha, H. Improvement of Salt Tolerance in Durum Wheat (Triticum Durum Desf.) by Auxin and Kenitin Application. Eur. Sci. J. 2017, 13. [CrossRef]

27. Alam, M.; Khan, M.A.; Imtiaz, M.; Khan, M.A.; Naeem, M.; Shah, S.A.; Samiullah; Ahmad, S.H.; Khan, L. Indole-3-Acetic Acid Rescues Plant Growth and Yield of Salinity Stressed Tomato (Lycopersicon Esculentum L.). Gesunde Pflanz. 2020, 72, 87-95. [CrossRef]

28. Kaya, C.; Tuna, A.L.; Okant, A.M. Effect of Foliar Applied Kinetin and Indole Acetic Acid on Maize Plants Grown under Saline Conditions. Turk. J. Agric. For. 2010, 34, 529-538.

29. Egamberdieva, D. Alleviation of Salt Stress by Plant Growth Regulators and IAA Producing Bacteria in Wheat. Acta Physiol. Plant. 2009, 31, 861-864. [CrossRef]

30. Hönig, M.; Plíhalová, L.; Husičková, A.; Nisler, J.; Doležal, K. Role of Cytokinins in Senescence, Antioxidant Defence and Photosynthesis. Int. J. Mol. Sci. 2018, 19, 4045. [CrossRef]

31. Liu, Y.; Zhang, M.; Meng, Z.; Wang, B.; Chen, M. Research Progress on the Roles of Cytokinin in Plant Response to Stress. Int. J. Mol. Sci. 2020, 21, 6574. [CrossRef] [PubMed]

32. Choi, J.; Hwang, I. Cytokinin: Perception, Signal Transduction, and Role in Plant Growth and Development. J. Plant Biol. 2007, 50, 98-108. [CrossRef]

33. Ryu, H.; Cho, Y.-G. Plant Hormones in Salt Stress Tolerance. J. Plant Biol. 2015, 58, 147-155. [CrossRef]

34. Wu, X.; He, J.; Chen, J.; Yang, S.; Zha, D. Alleviation of Exogenous 6-Benzyladenine on Two Genotypes of Eggplant (Solanum Melongena Mill.) Growth under Salt Stress. Protoplasma 2014, 251, 169-176. [CrossRef]

35. Akter, N.; Islam, M.R.; Karim, M.A.; Hossain, T. Alleviation of Drought Stress in Maize by Exogenous Application of Gibberellic Acid and Cytokinin. J. Crop Sci. Biotechnol. 2014, 17, 41-48. [CrossRef]

36. Hu, J.; Ren, B.; Dong, S.; Liu, P.; Zhao, B.; Zhang, J. Comparative Proteomic Analysis Reveals That Exogenous 6-Benzyladenine (6-BA) Improves the Defense System Activity of Waterlogged Summer Maize. BMC Plant Biol. 2020, 20, 44. [CrossRef] [PubMed]

37. Bohra, A.; Pandey, M.K.; Jha, U.C.; Singh, B.; Singh, I.P.; Datta, D.; Chaturvedi, S.K.; Nadarajan, N.; Varshney, R.K. GenomicsAssisted Breeding in Four Major Pulse Crops of Developing Countries: Present Status and Prospects. Theor. Appl. Genet. 2014, 127, 1263-1291. [CrossRef] [PubMed]

38. Tavakkoli, E.; Paull, J.; Rengasamy, P.; McDonald, G.K. Comparing Genotypic Variation in Faba Bean (Vicia Faba L.) in Response to Salinity in Hydroponic and Field Experiments. Field Crops Res. 2012, 127, 99-108. [CrossRef]

39. Farooq, M.; Gogoi, N.; Hussain, M.; Barthakur, S.; Paul, S.; Bharadwaj, N.; Migdadi, H.M.; Alghamdi, S.S.; Siddique, K.H.M. Effects, Tolerance Mechanisms and Management of Salt Stress in Grain Legumes. Plant Physiol. Biochem. 2017, 118, $199-217$. [CrossRef] [PubMed]

40. Watson, D.J.; Watson, M.A. Comparative Physiological Studies on the Growth of Field Crops. Ann. Appl. Biol. 1953, 40, 1-37. [CrossRef]

41. Bates, L.S.; Waldren, R.P.; Teare, I.D. Rapid Determination of Free Proline for Water-Stress Studies. Plant soil 1973, 39, $205-207$. [CrossRef]

42. Fales, F.W. The Assimilation and Degradation of Carbohydrates by Yeast Cells. J. Biol. Chem. 1951, 193, 113-124. [CrossRef]

43. Lowry, O.H.; Rosebrough, N.J.; Farr, A.L.; Randall, R.J. Protein Measurement with the Folin Phenol Reagent. J. Biol. Chem. 1951, 193, 265-275. [CrossRef]

44. Moore, S.; Stein, W.H. Photometric Nin-Hydrin Method for Use in the Ehromatography of Amino Acids. J. Biol. Chem. 1948, 176, 367-388. [CrossRef]

45. Tahjib-Ul-Arif, M.; Sayed, M.A.; Islam, M.M.; Siddiqui, M.N.; Begum, S.N.; Hossain, M.A. Screening of Rice Landraces (Oryza Sativa L.) for Seedling Stage Salinity Tolerance Using Morpho-Physiological and Molecular Markers. Acta Physiol. Plant. 2018, 40, 70. [CrossRef]

46. Schwarzenbach, G.; Biedermann, W.; Komplexone, X. Erdalkalikomplexe von o, o'-Dioxyazofarbstoffen. Helv. Chim. Acta 1948, 31, 678-687. [CrossRef] [PubMed]

47. Heath, R.L.; Packer, L. Photoperoxidation in Isolated Chloroplasts: I. Kinetics and Stoichiometry of Fatty Acid Peroxidation. Arch. Biochem. Biophys. 1968, 125, 189-198. [CrossRef]

48. Mukherjee, S.; Choudhuri, M. Implications of Water Stress-induced Changes in the Levels of Endogenous Ascorbic Acid and Hydrogen Peroxide in Vigna Seedlings. Physiol. Plant. 1983, 58, 166-170. [CrossRef]

49. Scebba, F.; Sebastiani, L.; Vitagliano, C. Protective Enzymes against Activated Oxygen Species in Wheat (Triticum Aestivum L.) Seedlings: Responses to Cold Acclimation. J. Plant Physiol. 1999, 155, 762-768. [CrossRef]

50. Aebi, H. Catalase in vitro. In Methods in Enzymology; Elsevier: Amsterdam, The Netherlands, 1984; Volume 105, pp. 121-126, ISBN 0076-6879.

51. Maehly, A.; Chance, B. Catalases and Peroxidases. Methods Biochem. Anal. 1954, 1, 357-424.

52. Chen, G.-X.; Asada, K. Inactivation of Ascorbate Peroxidase by Thiols Requires Hydrogen Peroxide. Plant Cell Physiol. 1992, 33, 117-123. [CrossRef]

53. Hames, B.D.; Rickwood, D. Gel Electrophoresis of Nucleic Acids. A Practical Approach, 2nd ed.; IRL Press: New York, NY, USA, 1990. 
54. Reed, S.H.; You, Z.; Friedberg, E.C. The Yeast RAD7 and RAD16 Genes Are Required for Postincision Events during Nucleotide Excision Repair: In vitro and in vivo Studies with rad7 and Rad16 Mutants and Purification of a Rad7/Rad16-containing Protein Complex. J. Biol. Chem. 1998, 273, 29481-29488. [CrossRef] [PubMed]

55. Sohag, A.A.M.; Tahjib-Ul-Arif, M.; Polash, M.A.S.; Chowdhury, M.B.; Afrin, S.; Burritt, D.J.; Murata, Y.; Hossain, M.A.; Hossain, M.A. Exogenous Glutathione-Mediated Drought Stress Tolerance in Rice (Oryza Sativa L.) Is Associated with Lower Oxidative Damage and Favorable Ionic Homeostasis. Iran J. Sci. Technol. Trans. Sci. 2020, 44, 955-971. [CrossRef]

56. Shahid, M.A.; Sarkhosh, A.; Khan, N.; Balal, R.M.; Ali, S.; Rossi, L.; Gómez, C.; Mattson, N.; Nasim, W.; Garcia-Sanchez, F. Insights into the Physiological and Biochemical Impacts of Salt Stress on Plant Growth and Development. Agronomy 2020, 10, 938. [CrossRef]

57. Samineni, S.; Siddique, K.H.M.; Gaur, P.M.; Colmer, T.D. Salt Sensitivity of the Vegetative and Reproductive Stages in Chickpea (Cicer Arietinum L.): Podding Is a Particularly Sensitive Stage. Environ. Exp. Bot. 2011, 71, 260-268. [CrossRef]

58. Dawood, M.G.; El-Metwally, I.M.; Abdelhamid, M.T. Physiological Response of Lupine and Associated Weeds Grown at Salt-Affected Soil to A-tocopherol and Hoeing Treatments. Gesunde Pflanz. 2016, 68, 117-127. [CrossRef]

59. El-Awadi, M.; Sadak, M.; Dawood, M.; Khater, M.; Elashtokhy, M. Amelioration the Adverse Effects of Salinity Stress by Using $\gamma$-Radiation in Faba Bean Plants. Bull. Natl. Res. Cent. 2017, 41, 293-310.

60. Javid, M.G.; Sorooshzadeh, A.; Sanavy, S.A.M.M.; Allahdadi, I.; Moradi, F. Effects of the Exogenous Application of Auxin and Cytokinin on Carbohydrate Accumulation in Grains of Rice under Salt Stress. Plant Growth Regul. 2011, 65, 305-313. [CrossRef]

61. Khalid, A.; Aftab, F. Effect of Exogenous Application of IAA and GA 3 on Growth, Protein Content, and Antioxidant Enzymes of Solanum Tuberosum L. Grown in Vitro under Salt Stress. Vitro Cell. Dev. Biol. Plant 2020, 56, 377-389. [CrossRef]

62. Sá, F.V.d.S.; Brito, M.E.B.; Silva, L.d.A.; Moreira, R.C.L.; Paiva, E.P.d.; Souto, L.S. Exogenous Application of Phytohormones Mitigates the Effect of Salt Stress on Carica Papaya Plants. Rev. Bras. Eng. Agríc. Ambient. 2020, 24, 170-175. [CrossRef]

63. Muhammad, N.; Manghwar, H.; Quraishi, U.; Chaudhary, H.; Munis, M. IAA (Indole-3-Acetic Acid) Induces Biochemical and Physiological Changes in Wheat under Drought Stress. Philipp. Agric. Sci. 2015, 99.

64. Zhang, Y.; Li, Y.; Hassan, M.J.; Li, Z.; Peng, Y. Indole-3-Acetic Acid Improves Drought Tolerance of White Clover via Activating Auxin, Abscisic Acid and Jasmonic Acid Related Genes and Inhibiting Senescence Genes. BMC Plant Biol. 2020, 20, 150. [CrossRef]

65. Zhao, Y. Auxin Biosynthesis and Its Role in Plant Development. Annu Rev. Plant Biol. 2010, 61, 49-64. [CrossRef]

66. Liu, W.; Li, R.-J.; Han, T.-T.; Cai, W.; Fu, Z.-W.; Lu, Y.-T. Salt Stress Reduces Root Meristem Size by Nitric Oxide-Mediated Modulation of Auxin Accumulation and Signaling in Arabidopsis. Plant Physiol. 2015, 168, 343-356. [CrossRef] [PubMed]

67. Iqbal, M.; Ashraf, M.; Jamil, A. Seed Enhancement with Cytokinins: Changes in Growth and Grain Yield in Salt Stressed Wheat Plants. Plant Growth Regul. 2006, 50, 29-39. [CrossRef]

68. Ma, X.; Zhang, J.; Huang, B. Cytokinin-Mitigation of Salt-Induced Leaf Senescence in Perennial Ryegrass Involving the Activation of Antioxidant Systems and Ionic Balance. Environ. Exp. Bot. 2016, 125, 1-11. [CrossRef]

69. Fazeli, M.; Naderi, D. Effects of 6-Benzylaminopurine and Salinity Stress on Flowering and Biochemical Characteristics of Winter Jasmine (Jasminum Nudiflorum L.). J. Ornam. Plants 2019, 9, 41-53.

70. Hayat, S.; Yadav, S.; Wani, D.A.; Irfan, M.; Alyemeni, M.; Ahmad, A. Impact of Sodium Nitroprusside on Nitrate Reductase, Proline Content, and Antioxidant System in Tomato under Salinity Stress. Hortic. Environ. Biotechnol. 2012, 53, 362-367. [CrossRef]

71. Zulfiqar, F.; Akram, N.A.; Ashraf, M. Osmoprotection in Plants under Abiotic Stresses: New Insights into a Classical Phenomenon. Planta 2020, 251, 1-17. [CrossRef]

72. Mansour, M.M.F.; Ali, E.F. Evaluation of Proline Functions in Saline Conditions. Phytochemistry 2017, 140, 52-68. [CrossRef] [PubMed]

73. Hasanuzzaman, M.; Anee, T.I.; Bhuiyan, T.F.; Nahar, K.; Fujita, M. Emerging role of osmolytes in enhancing abiotic stress tolerance in rice. In Advances in Rice Research for Abiotic Stress Tolerance; Elsevier: Hoboken, NJ, USA, 2019; pp. 677-708.

74. Dawood, M.F.; Sohag, A.A.M.; Tahjib-Ul-Arif, M.; Latef, A.A.H.A. Hydrogen Sulfide Priming Can Enhance the Tolerance of Artichoke Seedlings to Individual and Combined Saline-Alkaline and Aniline Stresses. Plant Physiol. Biochem. 2021, 159, 347-362. [CrossRef]

75. Hildebrandt, T.M. Synthesis versus Degradation: Directions of Amino Acid Metabolism during Arabidopsis Abiotic Stress Response. Plant Mol. Biol. 2018, 98, 121-135. [CrossRef] [PubMed]

76. Batista-Silva, W.; Heinemann, B.; Rugen, N.; Nunes-Nesi, A.; Araújo, W.L.; Braun, H.-P.; Hildebrandt, T.M. The Role of Amino Acid Metabolism during Abiotic Stress Release. Plant Cell Environ. 2019, 42, 1630-1644. [CrossRef] [PubMed]

77. Gadallah, M.A.A. Effects of Indole-3-Acetic Acid and Zinc on the Growth, Osmotic Potential and Soluble Carbon and Nitrogen Components of Soybean Plants Growing under Water Deficit. J. Arid Environ. 2000, 44, 451-467. [CrossRef]

78. Kaya, C.; Akram, N.A.; Ashraf, M. Kinetin and Indole Acetic Acid Promote Antioxidant Defense System and Reduce Oxidative Stress in Maize (Zea Mays L.) Plants Grown at Boron Toxicity. J. Plant Growth Regul. 2018, 37, 1258-1266. [CrossRef]

79. Hakim, M.; Juraimi, A.; Hanafi, M.; Ismail, M.; Rafii, M.; Islam, M.; Selamat, A. The Effect of Salinity on Growth, Ion Accumulation and Yield of Rice Varieties. J. Anim. Plant Sci. 2014, 24, 874-885.

80. Mahmud, S.; Sharmin, S.; Chowdhury, B.L.; Hossain, M.A. Research Article Effect of Salinity and Alleviating Role of Methyl Jasmonate in Some Rice Varieties. Asian J. Plant Sci. 2017, 16, 87-93. [CrossRef]

81. Orlovsky, N.; Japakova, U.; Zhang, H.; Volis, S. Effect of Salinity on Seed Germination, Growth and Ion Content in Dimorphic Seeds of Salicornia Europaea L.(Chenopodiaceae). Plant Divers. 2016, 38, 183-189. [CrossRef] [PubMed] 
82. Guo, W. Chapter 11-Magnesium homeostasis mechanisms and magnesium use efficiency in plants. In Plant Macronutrient Use Efficiency; Hossain, M.A., Kamiya, T., Burritt, D.J., Tran, L.-S.P., Fujiwara, T., Eds.; Academic Press: Cambridge, MA, USA, 2017; pp. 197-213, ISBN 978-0-12-811308-0.

83. Sun, J.; Li, L.; Liu, M.; Wang, M.; Ding, M.; Deng, S.; Lu, C.; Zhou, X.; Shen, X.; Zheng, X.; et al. Hydrogen Peroxide and Nitric Oxide Mediate K+/Na+ Homeostasis and Antioxidant Defense in NaCl-Stressed Callus Cells of Two Contrasting Poplars. Plant Cell Tiss. Organ Cult. 2010, 103, 205-215. [CrossRef]

84. Tahjib-Ul-Arif, M.; Siddiqui, M.N.; Sohag, A.A.M.; Sakil, M.A.; Rahman, M.M.; Polash, M.A.S.; Mostofa, M.G.; Tran, L.-S.P. Salicylic Acid-Mediated Enhancement of Photosynthesis Attributes and Antioxidant Capacity Contributes to Yield Improvement of Maize Plants Under Salt Stress. J. Plant Growth Regul. 2018, 37, 1318-1330. [CrossRef]

85. Guimarães, F.V.A.; de Lacerda, C.F.; Marques, E.C.; de Miranda, M.R.A.; de Abreu, C.E.B.; Prisco, J.T.; Gomes-Filho, E. Calcium Can Moderate Changes on Membrane Structure and Lipid Composition in Cowpea Plants under Salt Stress. Plant Growth Regul. 2011, 65, 55-63. [CrossRef]

86. Sadak, M.; Elhamid, A.; Mahmoud, M. Glutathione Induced Antioxidant Protection against Salinity Stress in Chickpea (Cicer Arietinum L.) Plant. Egypt. J. Bot 2017, 57, 293-302. [CrossRef]

87. Latif, M.; Akram, N.A.; Ashraf, M. Regulation of Some Biochemical Attributes in Drought-Stressed Cauliflower (Brassica Oleracea L.) by Seed Pre-Treatment with Ascorbic Acid. J. Hortic. Sci. Biotechnol. 2016, 91, 129-137. [CrossRef]

88. Akram, N.A.; Iqbal, M.; Muhammad, A.; Ashraf, M.; Al-Qurainy, F.; Shafiq, S. Aminolevulinic Acid and Nitric Oxide Regulate Oxidative Defense and Secondary Metabolisms in Canola (Brassica Napus L.) under Drought Stress. Protoplasma 2018, 255, 163-174. [CrossRef]

89. Roy, S.; Negrao, S.; Tester, M. Salt Resistant Crop Plants. Curr. Opin. Biotechnol. 2014, 26, 115-124. [CrossRef]

90. Öztürk, M. Anticholinesterase and Antioxidant Activities of Savoury (Satureja Thymbra L.) with Identified Major Terpenes of the Essential Oil. Food Chem. 2012, 134, 48-54. [CrossRef]

91. Eser, A.; Aydemir, T. The Effect of Kinetin on Wheat Seedlings Exposed to Boron. Plant Physiol. Biochem. 2016, 108, 158-164. [CrossRef] [PubMed]

92. Shah, S. Kinetin Improves Photosynthetic and Antioxidant Responses of Nigella Sativa to Counteract Salt Stress. Russ. J. Org. Chem. 2011, 58, 454-459. [CrossRef]

93. Bavei, V.; Shiran, B.; Khodambashi, M.; Ranjbar, A. Protein Electrophoretic Profiles and Physiochemical Indicators of Salinity Tolerance in Sorghum (Sorghum Bicolor L.). Afr. J. Biotechnol. 2011, 10, 2683-2697. [CrossRef]

94. Parker, R.; Flowers, T.J.; Moore, A.L.; Harpham, N.V.J. An Accurate and Reproducible Method for Proteome Profiling of the Effects of Salt Stress in the Rice Leaf Lamina. J. Exp. Bot. 2006, 57, 1109-1118. [CrossRef]

95. Younis, M.E.; Hasaneen, M.N.A.; Kazamel, A.M.S. Plant Growth, Metabolism and Adaptation in Relation to Stress Conditions. XXVII. Can Ascorbic Acid Modify the Adverse Effects of $\mathrm{NaCl}$ and Mannitol on Amino Acids, Nucleic Acids and Protein Patterns in Vicia Faba Seedlings? Protoplasma 2009, 235, 37-47. [CrossRef] [PubMed]

96. Polenta, G.A.; Calvete, J.J.; González, C.B. Isolation and Characterization of the Main Small Heat Shock Proteins Induced in Tomato Pericarp by Thermal Treatment. FEBS J. 2007, 274, 6447-6455. [CrossRef] [PubMed]

97. Sobhanian, N.; Pakniyat, H.; Kordshooli, M.A.; Dorostkar, S.; Aliakbari, M.; Nasiri, Z.F. Electrophresis Study of Wheat (Triticum Aestivum L.) Protein Changes under Salinity Stress. Sci. Res. 2016, 4, 33-36. [CrossRef] 